University of Nebraska - Lincoln

DigitalCommons@University of Nebraska - Lincoln

Faculty Publications in Food Science and Technology

Food Science and Technology Department

$10-2016$

\title{
Comparison of Hermetic Storage of Wheat with Traditional Storage Methods in India
}

\author{
Pavel Somavat \\ University of Illinois at Urbana-Champaign \\ Haibo Huang \\ University of Illinois at Urbana-Champaign \\ Sunil Kumar \\ CCS Haryana Agricultural University \\ Mukesh K. Garg \\ CCS Haryana Agricultural University \\ Mary-Grace C. Danao \\ University of Illinois at Urbana-Champaign, mdanao2@unl.edu
}

See next page for additional authors

Follow this and additional works at: https://digitalcommons.unl.edu/foodsciefacpub

Part of the Food Science Commons

Somavat, Pavel; Huang, Haibo; Kumar, Sunil; Garg, Mukesh K.; Danao, Mary-Grace C.; Singh, Vijay; Paulsen, Marvin R.; and Rausch, Kent D., "Comparison of Hermetic Storage of Wheat with Traditional Storage Methods in India" (2016). Faculty Publications in Food Science and Technology. 290.

https://digitalcommons.unl.edu/foodsciefacpub/290

This Article is brought to you for free and open access by the Food Science and Technology Department at DigitalCommons@University of Nebraska - Lincoln. It has been accepted for inclusion in Faculty Publications in Food Science and Technology by an authorized administrator of DigitalCommons@University of Nebraska Lincoln. 


\section{Authors}

Pavel Somavat, Haibo Huang, Sunil Kumar, Mukesh K. Garg, Mary-Grace C. Danao, Vijay Singh, Marvin R. Paulsen, and Kent D. Rausch 


\title{
COMPARISON OF HERMETIC STORAGE OF WHEAT WITH TRADITIONAL STORAGE METHODS IN INDIA
}

\author{
P. Somavat, H. Huang, S. Kumar, M. K. Garg, M. C. Danao, \\ V. Singh, M. R. Paulsen, K. D. Rausch
}

\begin{abstract}
India is among the countries experiencing high postharvest losses. Four hermetic bags, two metallic bins, and two gunny bag (also known as jute or burlap bag) piles each containing 1 tonne of wheat were instrumented with temperature, relative humidity, and carbon dioxide sensors. Representative samples from each structure were collected each month and tests for moisture, germination, insect-damaged grain, and milling yield were performed. After nine months, wheat stored in hermetic bags had higher germination (87\%) and lower insect-damaged grain percentages $(0 \%$ to $0.33 \%$ with a mean value of $0.2 \%$ ). Hermetic bags with deliberately introduced Rhyzopertha dominica successfully eliminated the pests. Gunny bag piles had infestations; metallic bins also were infested. Wheat moisture content in all structures varied depending upon ambient conditions; moisture variation was largest in gunny bag piles. Milling yields were lowest for gunny bag piles. Hermetic bags can be an effective and environmentally friendly solution for reducing storage losses of wheat in India.
\end{abstract}

Keywords. Hermetic bags, Postharvest losses, Sensors, Storage, Wheat.

W heat and rice are the major staple crops of India, which feed most of its 1.27 billion people. In 2012-2013, total food grain production of India was 257 million tonnes (Indian Council of Agricultural Research, 2014). According to an Indian government report (National Sample Survey Organization, 2010), $19.4 \%$ of the rural households and $20.5 \%$ of urban households had a daily caloric intake of less than $2160 \mathrm{kcal}$ per day and almost $46 \%$ of the children were malnourished. According to a recent report by the Food and Agriculture Organization (2009), despite these challenges, India can feed its growing population and still be able to export food grains provided it can reduce spoilage of food staples and improve infrastructure.

According to Kader (2005), almost $95 \%$ of agricultural research investments for the last 30 years have been focused on increasing productivity and only $5 \%$ on reducing postharvest losses (PHL). Conservative estimates place postharvest cereal losses in India at $6 \%$ while more realistic figures by

Submitted for review in February 2016 as manuscript number PRS 11792; approved for publication by the Processing Systems Community of ASABE in October 2016. Presented at the 2014 ASABE Annual Meeting as Paper No. 141898076.

The authors are Pavel Somavat, Graduate Student, Haibo Huang, Assistant Professor, Department of Agricultural \& Biological Engineering, University of Illinois at Urbana-Champaign, Urbana, Illinois; Sunil Kumar, Graduate Student, Mukesh K. Garg, Professor, Department of Agricultural Processing \& Energy, CCS Haryana Agricultural University, Hisar, India; Mary-Grace C. Danao, ASABE Member, Assistant Professor, Vijay Singh, ASABE Member, Professor, Marvin R. Paulsen, ASABE Fellow, Professor Emeritus, and Kent D. Rausch, ASABE Member, Associate Professor, Department of Agricultural \& Biological Engineering, University of Illinois at Urbana-Champaign, Urbana, Illinois. Corresponding author: Kent D. Rausch, Department of Agricultural \& Biological Engineering, University of Illinois at Urbana-Champaign, Urbana, IL 61801; phone: 217-265-0697; e-mail: krausch@illinois.edu.
Food and Agriculture Organization and a regional study estimate these losses to be 7\% to 15\% (Food and Agriculture Organization, 1994; Yadav and Garg, 2010). Indian Ministry of Food and Civil Supplies estimated PHL of food grains to be around $10 \%$ of total production (Basavaraja et al., 2007). Such wastage not only results in financial losses but also contributes to greenhouse gas emissions (Gustavsson et al., 2010). The Associated Chambers of Commerce and Industry in India predicted that overall PHL including fruits and vegetables in India has cost $\$ 41$ billion in 2013-2014 (ASSOCHAM, 2013).

In 2012-2013, total wheat production in India was 92 million tonnes; $76 \%$ of the total was harvested in the states of Uttar Pradesh, Punjab, Madhya Pradesh, and Haryana (Directorate of Wheat Research, 2013). According to a study by Grover and Singh (2013), almost 70\% of farm output in India is retained by farmers. Government agencies procure surplus wheat and rice from the farmers, facilitate storage of grain and transport grain from surplus to deficit states. To store grain, different storage practices are used such as gunny bags (jute or burlap bags), metallic bins and bulk storage in rooms. According to an Indian study of wheat storage practices in semi-arid regions, $42 \%$ of the farmers used gunny bags, $18 \%$ used bulk storage in rooms, and $11 \%$ used metallic bins (Kumawat, 2007).

Use of chemical fumigants has been a prominent method of controlling pests and microorganisms in stored grain (Navarro, 2006). However chemical fumigants, if employed improperly, leave harmful residues in the grain and are a potential health hazard for the person doing fumigation (Navarro, 2012). Gradually, major pests of stored cereals such as Rhyzopertha dominica and Liposcelis bostrychophila are developing resistance against commonly used chemical fumigants (Nayak et al., 2003; Collins et al., 2005; Lorini et al., 2007). 
Hermetic storage is a technique which involves storing cereals in airtight containers, such as polyvinyl chloride (PVC) bags. The process of respiration by grain, fungi, insects, and other microorganisms inside the bag causes depletion of $\mathrm{O}_{2}$ and a buildup of $\mathrm{CO}_{2}$ which inhibits further growth of insects and fungi inside the bag (Navarro, 2006; Subramanyam et al., 2012). Gradual decrease in $\mathrm{O}_{2}$ concentration and subsequent increase in $\mathrm{CO}_{2}$ concentration results in insect mortality inside the container without any application of chemical fumigants. Although hermetic bags are supposed to be completely airtight, however due to practical constraints complete air tightness is not achieved. These bags have been adopted increasingly in Latin America and Southeast Asia (Villers et al., 2006; Abalone et al., 2011).

In a study involving storage of corn, wheat, soybeans, and sunflower seeds in hermetic bags of 200 tonnes, gas composition of the interstitial atmosphere was measured and grain was sampled at the beginning and then after 45,80 , and 150 days (Bartosik et al., 2008). $\mathrm{CO}_{2}$ concentration in the bags ranged between $4.4 \%$ and $70.3 \%$ depending upon grain variety, moisture content, and outside temperature. No significant qualitative changes were observed after 150 days storage when initial moisture contents were kept within recommended ranges and no insect activity was reported. Butts et al. (2008) stored unshelled peanuts having initial moisture contents of $5.7 \%$ and $9.3 \%$ wet basis (w.b.) in flexible hermetically sealed plastic containers for 160 to 180 days and samples were taken at the beginning and at the end of the storage. Relatively faster $\mathrm{O}_{2}$ depletion was observed in peanuts with higher initial moisture content. In dry peanuts (5.7\% w.b.), it took 180 days for $\mathrm{O}_{2}$ concentration to decrease from $21 \%$ to $6 \%$ whereas for moist peanuts $(9.3 \%$ w.b.), $\mathrm{O}_{2}$ concentration quickly decreased from $21 \%$ to $1 \%$ during the first 12 days of storage. Fungal activity was observed at the top of the bags due to moisture migration which was more pronounced in peanuts with higher initial moisture content.

Insect respiration rates and metabolic activities usually are increased at an elevated temperature, causing more rapid depletion of $\mathrm{O}_{2}$ in hermetic bags, and insect mortality is increased correspondingly (Jayas and Jeyamkondan, 2002). Although different insect species have varying levels of tolerance to a modified atmosphere (Navarro and Donahaye, 2005), $35 \% \mathrm{CO}_{2}$ concentration for shorter duration is lethal to test insects even when $\mathrm{O}_{2}$ concentration is as high as $15 \%$. In absence of $\mathrm{CO}_{2}, \mathrm{O}_{2}$ concentrations below $3 \%$ are needed for effective control of insects, although $\mathrm{O}_{2}$ level below $1 \%$ is desired (Banks and Annis, 1990). Advances in hermetic storage technique include portable, multilayer bags with ultra-low oxygen permeability which has successfully resisted insects such as Prostephanus truncatus, Rhyzopertha dominica and Collosobruchus maculatus in stored maize, wheat and cowpea (Garcia-Lara et al 2013). Small metallic bins made from galvanized iron sheets are extensively used in developing countries by small scale framers to protect their produce (SDC, 2008a; CIMMYT, 2009; Tefera et al., 2011). Research efforts are focused on improving the air tightness of metallic bins and making them more resistant to insect infestation (SDC, 2008b; Yusuf and He, 2011).
The aim of this project was to provide unbiased measurements for comparison of two traditional Indian storage structures (metallic bins and gunny bags) to hermetic storage structures for wheat stored under typical north Indian conditions at Hisar, Haryana (latitude $29.1500^{\circ} \mathrm{N}$ and longitude $75.7000^{\circ} \mathrm{E}$ ). Most hermetic storage studies have been carried out in colder regions with distinctive cold seasons following harvest. North India provided a different challenge in terms of yearlong warm temperatures $\left(10^{\circ} \mathrm{C}\right.$ to $\left.37^{\circ} \mathrm{C}\right)$ and periods of high relative humidity ( $30 \%$ to $95 \%$ ). Secondly, no efforts have been published to compare hermetic bags to traditional storage methods under local conditions at a scale relative to the small farms and villages in northern India. We tested whether hermetic bags could be effective in reducing storage losses for small holder farmers. Specific objectives of the study were:

1. to monitor temperature (T), relative humidity (r.h.), and interstitial carbon dioxide concentrations in three types of storage structures suitable for small holder farmers and villages;

2. to compare quality characteristics of wheat such as moisture, germination, insect-damaged grain, and milling yield in hermetic bags with that of metallic bins and gunny bags; and

3. to quantify effects of wheat moisture content on changes in quality during hermetic storage.

\section{Materials ANd Methods}

\section{WhEAT STORAGE}

Freshly harvested seed grade wheat (8 tonnes) of the variety WH 711 was procured from the Chaudhary Charan Singh Haryana Agricultural University farm (Hisar, Haryana, India). Grain was cleaned and graded in a seed processing plant before being supplied. Four hermetic bags, namely H1, H2, H3, and H4 (GrainSafe III ${ }^{\mathrm{TM}}$, GrainPro Philippines, Inc., Subic Bay Freeport Zone, Philippines), were purchased with each having a capacity of 1 metric tonne and dimensions of $1.2 \times 1.2 \times 1.9 \mathrm{~m}(\mathrm{~L} \times \mathrm{W} \times \mathrm{H})$. These bags rested on metallic frames of $75 \times 75 \times 150 \mathrm{~cm}$ with rodent resistant devices on each leg. Each hermetic bag had an outer propathene jacket to act as a strength member. The target moisture content levels of wheat stored in hermetic bags were $12 \%$ and $14 \%$ (w.b.); actual wheat moisture content levels for all storage structures are summarized in table 1. Two metallic bins (M1 and M2) made up of 22 gauge galvanized steel sheets with removable lid closures at the top fixed with riveted hinges, each having $2 \mathrm{~m}$ height, and $1 \mathrm{~m}$ diameter contained approximately 1 tonne wheat with a moisture content of $12 \%$ (w.b.). These bins were manufactured by local artisans and cost about US $\$ 36$ per piece, wheat flour and water dough was used to make them airtight as is common practice in India. Forty $50 \mathrm{~kg}$ gunny bags made up of jute also known as burlap bags were procured with dimensions of $(84 \times 50 \times 20 \mathrm{~cm})$. Two piles of 20 gunny bags (B1 and B2) each were stacked side by side with $12 \%$ initial moisture content. All storage structures were placed in a non-climate controlled room, covered on all sides, and naturally ventilated. Wheat was delivered in the third week of July and was 
Table 1. Overview of the experimental setup ( 1 tonne per replicate).

\begin{tabular}{cccc}
\hline No. & Storage Method & $\begin{array}{c}\text { Treatment } \\
\text { Name }\end{array}$ & $\begin{array}{c}\text { Moisture } \\
\text { Content (w.b.) }\end{array}$ \\
\hline 1 & Hermetic storage & H1 & $11.5 \%$ \\
2 & Hermetic storage & H2 ${ }^{\text {[a] }}$ & $11.8 \%$ \\
3 & Hermetic storage & H3 & $13.4 \%$ \\
4 & Hermetic storage & H4\# & $13.4 \%$ \\
5 & Metallic bin & M1 & $11.8 \%$ \\
6 & Metallic bin & M2 & $11.7 \%$ \\
7 & Gunny bag pile & B1 & $12.2 \%$ \\
8 & Gunny bag pile & B2 & $12.2 \%$ \\
\hline
\end{tabular}

Hermetic bags with introduction of 80 adult specimens of Rhyzopertha dominica on 13 August 2013.

spread uniformly on the floor and was sprinkled with the required amount of water and mixed thoroughly to obtain desired moisture content (table 1). No chemical treatment/insecticides were employed in any treatment. Individual experiments started on 22 July 2013. To test the effectiveness of hermetic bags, 80 adult specimens of the lesser grain borer (Rhyzopertha dominica) were introduced into two of the bags on 13 August 2013.

\section{SENSOR INSTALLATION}

During storage, temperature, relative humidity and $\mathrm{CO}_{2}$ concentration were measured at fixed intervals for each of the hermetic bags, metallic bins and gunny bag piles. Initially the measurement interval was set at one reading per $h$ until 26 October 2013. Then to increase battery life, the measurement interval was set to one reading per $6 \mathrm{~h}$. Temperature and humidity sensors (Track-It ${ }^{\mathrm{TM}}$ Temperature and Humidity Data Loggers, MicroDaq.com, Ltd., Contoocook, N.H.) with RH measurement accuracy of $\pm 5 \%(0-100 \%$ RH $)$ and temperature measurement accuracy of $\pm 0.5 \%\left(0-60^{\circ} \mathrm{C}\right)$ were installed at top and bottom levels inside each storage structure. The upper sensor represented grain conditions within 5 to $10 \mathrm{~cm}$ of the grain surface. The bottom sensor represented the grain lying within 5 to $10 \mathrm{~cm}$ of the bottom of the storage structure (fig. 1). For the gunny bag pile, individual sensors were placed in the gunny bags at the bottom and top levels. Gaston et al. (2009) reported that $\mathrm{CO}_{2}$ distribution was almost uniform in hermetic bags where the diameter was less than $3 \mathrm{~m}$. Therefore, only one $\mathrm{CO}_{2}$ sensor was installed in each bag, bin, and pile. The NDIR $\mathrm{CO}_{2}$ sensor (K-33 BLG 30\%, CO2meter.com, Ormond Beach, Fla.) with a detection range from $0 \%$ to $30 \% \mathrm{CO}_{2}$ with an accuracy of $\pm 0.2 \%$ volume $\mathrm{CO}_{2} \pm 3 \%$ of measured value was installed in the middle of each hermetic bag, metallic bin, and the midlevel gunny bag. The $\mathrm{CO}_{2}$ sensor was powered by a $9 \mathrm{~V}$ battery and had lower power consumption $(\sim 250 \mu \mathrm{A})$ with one measurement per $\mathrm{h}$. Same sensors were used for measuring T/r.h. $/ \mathrm{CO}_{2}$ in all the structures. A custom-made sensor mounting rod was designed using PVC pipes to mount the temperature, r.h., and $\mathrm{CO}_{2}$ sensors at top, middle, and bottom levels. Special chambers were designed to protect the sensors from the grain and provide wire mesh isolation to allow the interstitial air interact with the sensors. To prevent vertical flow of gasses in the PVC pipes, sensor isolation was provided by sealing the tubes using silicone sealant. Measurements were recorded on the built-in memory card of the sensors. Each sensor was connected with a USB cable which extended outside the storage structure to allow data transfer between the sensor and a laptop. Orifices cut in the hermetic bags allowed the exit of the USB cable and were sealed by silicone sealant to ensure that the structure remained sealed. However, it was found to be very difficult to perfectly seal the exit with a bundle consisting of three thick USB cables. Partially due to this and monthly sampling which involved opening and resealing of orifices, no hermeticity test was considered for the study (fig. 2).

\section{SAMPling Procedure}

Wheat samples were collected initially and then at 1 month intervals from each storage structure. Samples were collected from top, bottom, and middle layers of wheat in metallic bins and from top, bottom, and middle-level gunny bags. For hermetic bags, it was not easy to make orifices in the horizontal plane due to the outer propathene jacket, so a

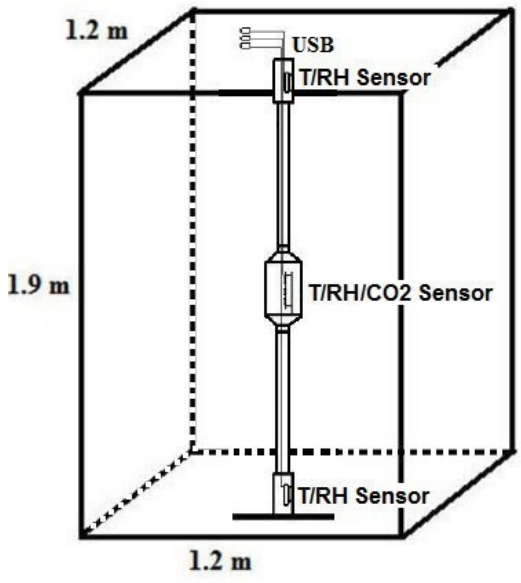

a. Hermetic bag

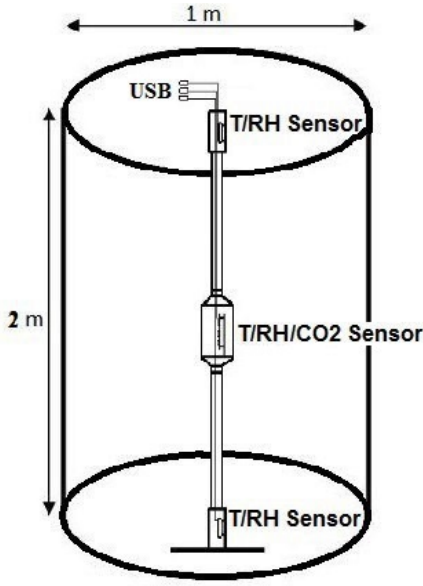

b. Metallic bin

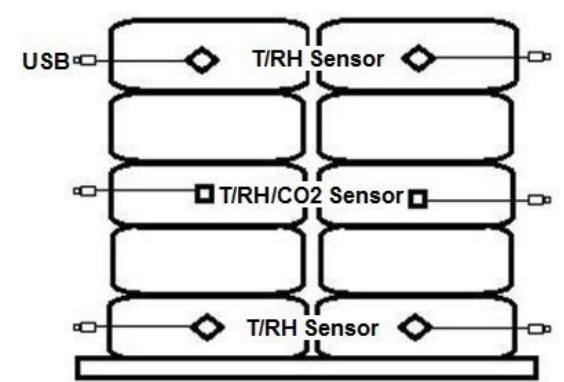

c. Gunny bag pile

Figure 1. For hermetic bags and metallic bins, temperature (T) and relative humidity (RH) sensors were mounted at the top and bottom of a sensor mounting rod while $\mathrm{T} / \mathrm{r}$.h./ $\mathrm{CO}_{2}$ sensors were mounted in the middle (USB: universal serial bus cable to computer). For gunny bag piles, these sensors were installed in the gunny bags at the top, middle, and bottom levels as shown. 

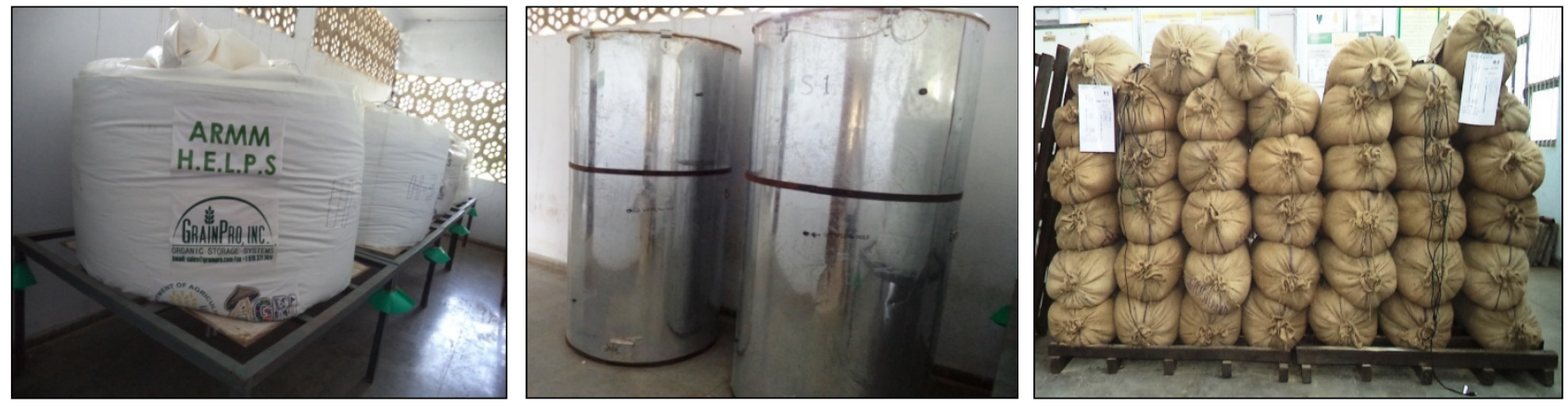

Figure 2. Experimental setup of hermetic bags, metallic bins, and gunny bag piles after the sensors were installed. Hermetic bags were mounted on stands with anti-rodent devices.

sampling orifice was made at the top. This restricted collection of samples from the center of the top, middle, and bottom layers of wheat and affected proper sampling to a certain extent. Sampling probes were used to collect samples from all three types of storage structures. After sampling, the orifices of hermetic bags were sealed using silicone sealant. Samples from top, middle, and bottom layer from an individual storage structure were pooled together (approx. $300 \mathrm{~g}$ ) to form representative samples for each month. These samples were sealed in plastic bags, stored at room temperature, and used for qualitative analysis. The storage experiment was conducted in duplicate for each of the four storage treatments (hermetic bag with low and high moisture content, metallic bins, and gunny bags). For each treatment, samples for quality characteristics (moisture, germination, insect-damaged kernel, and milling yield) were taken every month and were measured three times.

\section{Grain QUALITy EVALUATIONS Moisture Content}

All the moisture determinations in the study were made on wet basis using standard AOAC (2012) Method No. 930.15. Each $5 \mathrm{~g}$ ground sample was weighed and transferred to a pre dried, covered dish. Each weighed sample was dried in an air oven at $130 \pm 1^{\circ} \mathrm{C}$ for $2 \mathrm{~h}$. Dried samples were transferred to a desiccator, cooled to room temperature, and weighed. Moisture content (wet basis) in percent was calculated as the loss in weight divided by the original wet sample weight. This process was repeated three times for each storage structure.

\section{Warm Germination Test}

Three replications of 100 -seed tests for warm germination were performed according to the rules specified by (ISTA, 2011). The seeds were kept at $28^{\circ} \mathrm{C}$ and $95 \%$ r.h. and final count of germination was recorded on day eight; the number of normal seedlings was counted and expressed as percent germination.

\section{Insect-Damaged Kernel Test}

The insect-damaged kernel percentage test involved inspection of grain samples and identification of grain kernels damaged by insects. Broken or affected kernels were counted from a sample of 100 kernels and the process was repeated three times. Only the kernels which were bored by the insects were counted as the main aim was to only quantify the number of damaged kernels. The only insect species detected in structures was Rhyzopertha dominica and therefore assumed to be the dominant source of kernel damage.

\section{Milling Yield Test}

A Brabender Quardrumat Junior mill was used to determine milling behavior of tempered wheat grains and flour yield according to AACC (2002) Method No. 26-50. Three equal amounts of wheat samples from each treatment were tempered to $14 \%$ moisture level for removal of bran from endosperm. The mill was operated for $30 \mathrm{~min}$ for complete grinding. The ground samples were sieved into four fractions: thick bran, fine bran, fine flour and coarse flour (shorts). Fine flour and coarse flour were combined and weighed. Flour yield was calculated as:

$$
\text { Milling yield }(\%)=\frac{\text { Weight of flour obtained }}{\text { Weight of sample used }} \times 100
$$

\section{Data Analysis}

Each storage method was replicated twice and two way analysis of variance (ANOVA) and Tukey's test were used to compare moisture content, germination, insect-damaged kernels, and milling yield parameters prior to and after storage for all treatments using SAS Studio (SAS Institute, Cary, N.C.). The level selected to show statistical significance was $5 \%(\mathrm{p}<0.05)$.

\section{RESULTS}

\section{TEMPERATURE, RELATIVE HUMIDITY, AND $\mathrm{CO}_{2}$ VARIATIONS WITH TIME}

During the experiment, sensors suffered intermittent problems, most common being exhaustion of batteries earlier than expected; as a result, some data was not recorded for periods varying from hours to days resulting in discontinuities in figures 4-6. Average daily values of T, RH, and $\mathrm{CO}_{2}$ variations are displayed in all figures.

\section{Ambient Conditions}

During the experiment, ambient temperature and relative humidities were observed using a single $\mathrm{T} / \mathrm{r}$.h. sensor next to the storage structures at Hisar, Haryana, India (latitude $29.1500^{\circ} \mathrm{N}$ and longitude $75.7000^{\circ} \mathrm{E}$ ). Average daily ambient temperatures rose to $37^{\circ} \mathrm{C}$ during July 2013 and decreased to about $10^{\circ} \mathrm{C}$ in December 2013. Average daily relative humidity varied greatly and reached a maximum value of $95 \%$ in January 2014 and decreased to the lowest level of 30\% in April 2014 (fig. 3). 


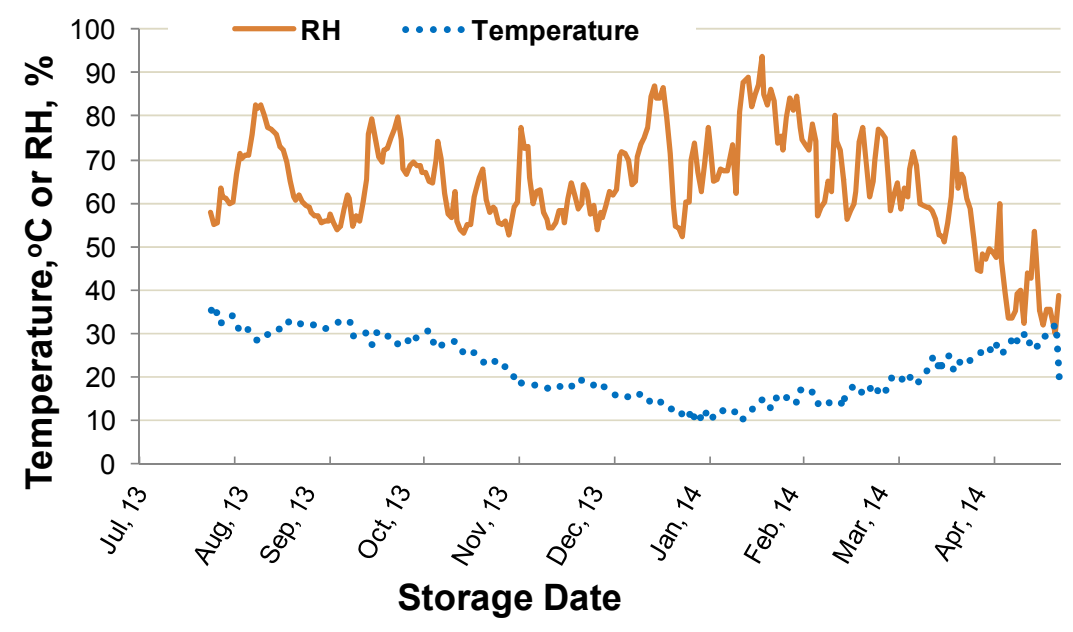

Figure 3. Ambient temperature and relative humidity variations from July 2013 to April 2014 (RH: relative humidity,\%).

\section{Variation of $\mathrm{CO}_{2}$ in Hermetic Bags}

Concentrations of $\mathrm{CO}_{2}$ inside the hermetic bags gradually increased and reached maximum levels after 45 to 50 days. The $\mathrm{CO}_{2}$ concentration increased with the increase in the outside temperature and decreased with the subsequent decrease of temperature. Highest mean $\mathrm{CO}_{2}$ concentration levels in hermetic bags $\mathrm{H} 1, \mathrm{H} 2, \mathrm{H} 3$, and $\mathrm{H} 4$ were $9.0 \%, 7.8 \%$, $8.8 \%$, and $9.0 \%$, respectively (fig. 4). Barring the months of October and November when $\mathrm{H} 1$ had the highest $\mathrm{CO}_{2}$ concentration, generally the bags with higher moisture content maintained higher $\mathrm{CO}_{2}$ concentrations as compared to the bags with lower initial moisture content. In cooler temperatures, grain respiration rate generally decreases resulting in decreased $\mathrm{CO}_{2}$ concentrations (Barreto et al., 2013). Lower grain and insect respiration rates during the cooler months coupled with lack of total hermeticity may have resulted in lower $\mathrm{CO}_{2}$ concentrations in hermetic bags observed from January to March. $\mathrm{CO}_{2}$ concentrations decreased to $1 \%$ and $2 \%$ levels in January 2014 when temperatures were the lowest. During March and April increase in temperatures, a second increase was observed in early April 2014 with $\mathrm{CO}_{2}$ concentrations again reaching 5\% to $8 \%$ levels. Results were similar to Gaston et al. (2009) where wheat was stored in a
200 tonne bag of $60 \mathrm{~m}$ length and $2.70 \mathrm{~m}$ diameter. In dry wheat ( $12.5 \%$ w.b.), $\mathrm{CO}_{2}$ concentration inside the bag increased to $4.4 \%, 8.7 \%$, and $13.0 \%$ in 5,45 , and 100 days, respectively; $\mathrm{O}_{2}$ concentration decreased to $14.7 \%, 12.6 \%$, and $10.4 \%$ in 5,45 , and 100 days, respectively. For wet wheat ( $16.4 \%$ w.b.), $\mathrm{CO}_{2}$ concentration increased to $18.9 \%$ in 5 days while $\mathrm{O}_{2}$ concentration decreased to $5.5 \%$ during the same duration (Gaston et al., 2009).

It was observed that the hermetic bags failed to maintain $\mathrm{CO}_{2}$ levels as reported by Darby and Caddick (2007). It was very difficult to completely seal the orifice with a bundle of three USB cables exiting, therefore the bags were not completely hermetic and $\mathrm{CO}_{2}$ concentration depended upon balance of the respiration rate and exchange rate from the outside. Lower $\mathrm{CO}_{2}$ levels in combination with low temperatures controlled infestations. This has been reported in a similar field study in Australia (Darby and Caddick, 2007). Control of infestation in this case cannot be solely ascribed to $\mathrm{CO}_{2}$ concentrations in hermetic bags, most probably resulting lower $\mathrm{O}_{2}$ concentrations played a part as it has been shown that $<2 \% \mathrm{O}_{2}$ concentration is lethal for storage pests (Persons and Sorenson, 1970). There was no significant change in $\mathrm{CO}_{2}$ concentrations in hermetic bags immediately after periodic sampling as is attested by sensor readings (fig. 4).

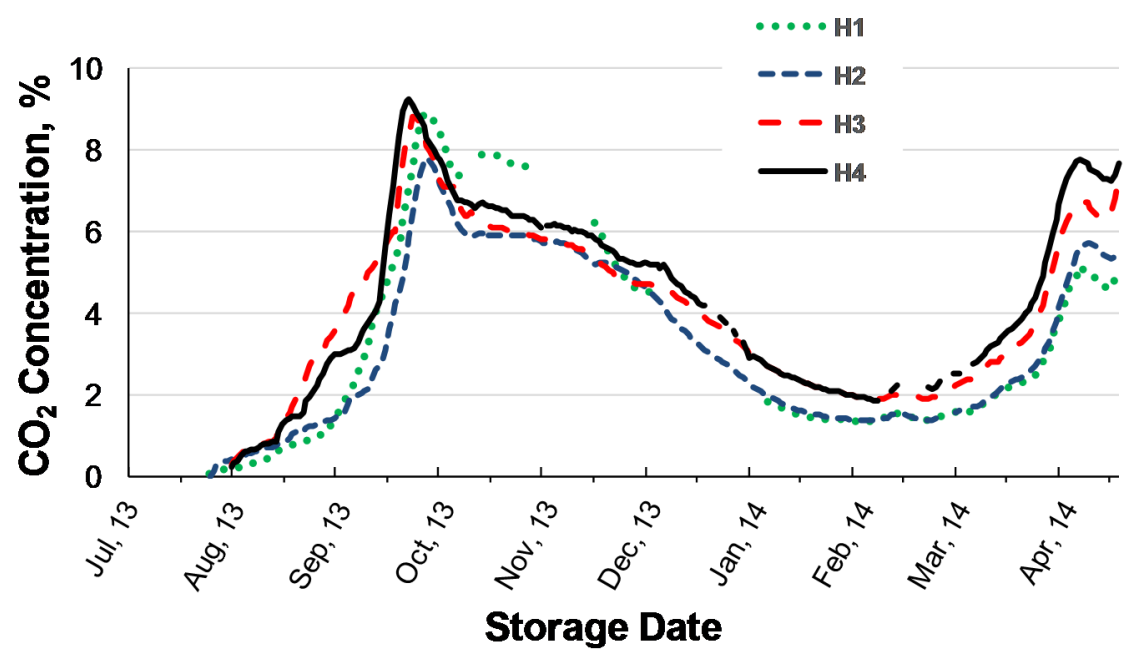

Figure 4. Concentrations of $\mathrm{CO}_{2}$ in hermetic bags $\mathrm{H1}, \mathrm{H} 2, \mathrm{H3}$, and $\mathrm{H} 4$ (see table 1). 
Variation of $\mathrm{CO}_{2}$ in Metallic Bins and Gunny Bags

Highest $\mathrm{CO}_{2}$ levels in metallic bins were $2 \%$ and $2.4 \%$ in $\mathrm{M} 1$ and $\mathrm{M} 2$, while $\mathrm{CO}_{2}$ levels in gunny bag piles mostly corresponded with the ambient levels. These levels are consistent with the nature of these structures; metallic bins acted as a sort of barrier for gas flow while gunny bags facilitated easy flow of gases in and outside (fig. 5).

\section{Temperature/r.h. Variations in Hermetic Bags}

Relative humidity variations were minimal inside the hermetic bags in comparison to the other two treatments (figs. $6 \mathrm{a}$ and $6 \mathrm{~b}$ ). However, r.h. variations were larger in the top layers of the bag compared to middle and bottom layers. Temperatures in the grain changed relative to outside temperatures; the upper layers of the grain experienced greater temperature variations resulting in greater r.h. variations in the top layers. Similar behavior for hermetic bags has been reported in other studies (Bartosik et al., 2008; Barreto et al., 2013). While sampling during the winter, some moisture condensation was observed inside the hermetic bags at the top, possibly due to warm air currents rising up through the grain, carrying the moisture with them and dumping it at the top.

\section{Temperature/r.h. Variations in Metallic Bins and Gunny Bag Piles}

Gunny bags demonstrated the largest internal r.h. variation dependence on the ambient conditions among all three storage techniques. This is due to free movement of moisture in and out of the gunny bags. Temperature variation inside the structures corresponded similarly with the ambient temperatures and these variations were greatest in gunny bags (figs. 7a and 7b).

\section{QUALITY CHARACTERISTICS Moisture Content}

In hermetic bags with higher initial moisture content, wheat moisture content varied from $11.3 \%$ to $13.4 \%$ while the bags with low initial moisture content, moisture varied from $8.3 \%$ to $11.8 \%$ (table 2 ). It has been reported that grain moisture contents do not change greatly $( \pm 1 \%)$ during hermetic storage period (Bartosik et al., 2008; Gaston et al., 2009; Ochandio et al., 2012). However, higher moisture content variation experienced in hermetic bags in this study can be attributed to moisture migration inside the bags which could not be quantified due to limitations on proper sampling and does not imply a net gain or loss of moisture. Due to structural integrity issues, we desisted from cutting sampling holes in hermetic bags on the sides and took samples from only one hole cut at the top. For metallic bins, the observed moisture content levels were $8.6 \%$ to $11.8 \%$. For gunny bag piles, this variation was the largest, moisture content varied from $8.3 \%$ to $13.9 \%$. In case of metallic bins and gunny bags, this variation could be due to moisture transfer from the outside to inside and vice versa. It was noticed that hermetic bags with low m.c. had lower r.h. variation $(45 \%-$ $55 \%)$ in comparison to metal bins $(60 \%-65 \%)$ and gunny bags $(60 \%-70 \%)$ with similar m.c. during most of the storage time, confirming that there was more influence of the ambient r.h. variations (55\%-80\%) in the last two treatments. In gunny bag treatments there was a trend for the m.c. variation to be similar to the ambient r.h. variations. Greater ambient temperature and r.h. variations observed during the storage were responsible for larger variations observed in comparison to other studies which were conducted in Argentina (Bartosik et al., 2008; Ochandio et al., 2010) where these variations are not so extreme.

\section{Warm Germination Test}

The warm germination test provides an indication of effectiveness of any storage technique. In all three structures, germination percentages of wheat after 9 months were lower relative to wheat at initial storage (table 2). At the end of 9 months, there were no differences of wheat germination between lower and higher initial m.c. hermetic bags (87\%). However, germination percentage in hermetic bags was higher in comparison to metallic bins ( $82 \%$ ) and gunny bags $(73 \%)$; despite the fact that insects were introduced into two of the hermetic bags. After 9 months, mean germination in hermetic bags was within the range of standard wheat seed germination recommendations of $>85 \%$ (ISTA, 2011). One

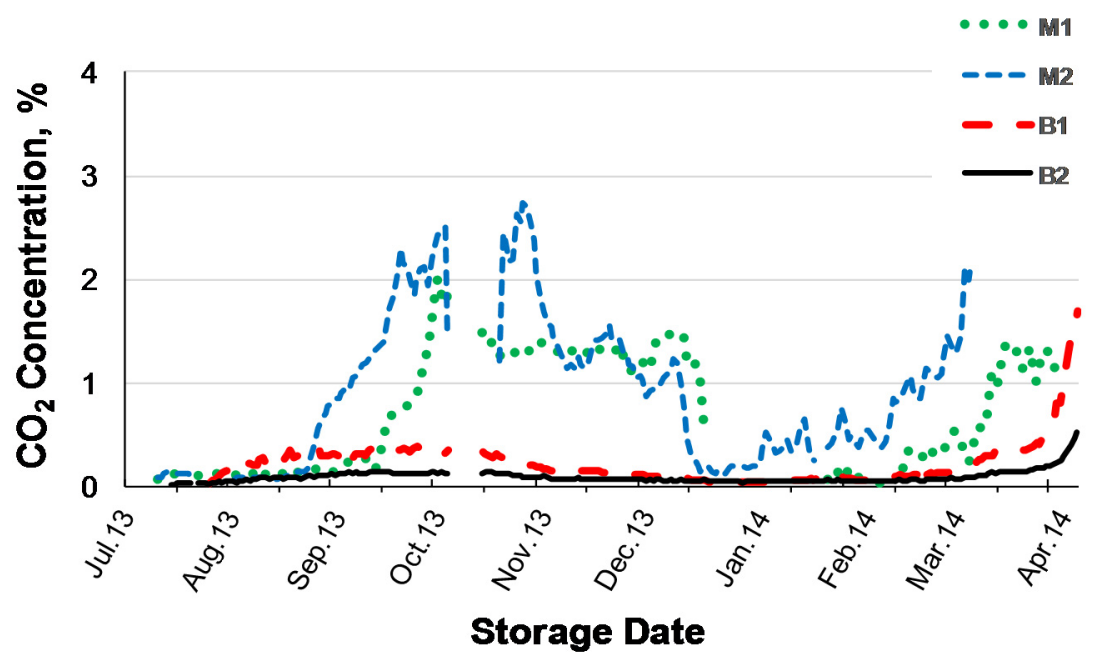

Figure 5. Concentrations of $\mathrm{CO}_{2}$ in metallic bins (M1, M2) and gunny bag piles (B1 and B2; see table 1). 


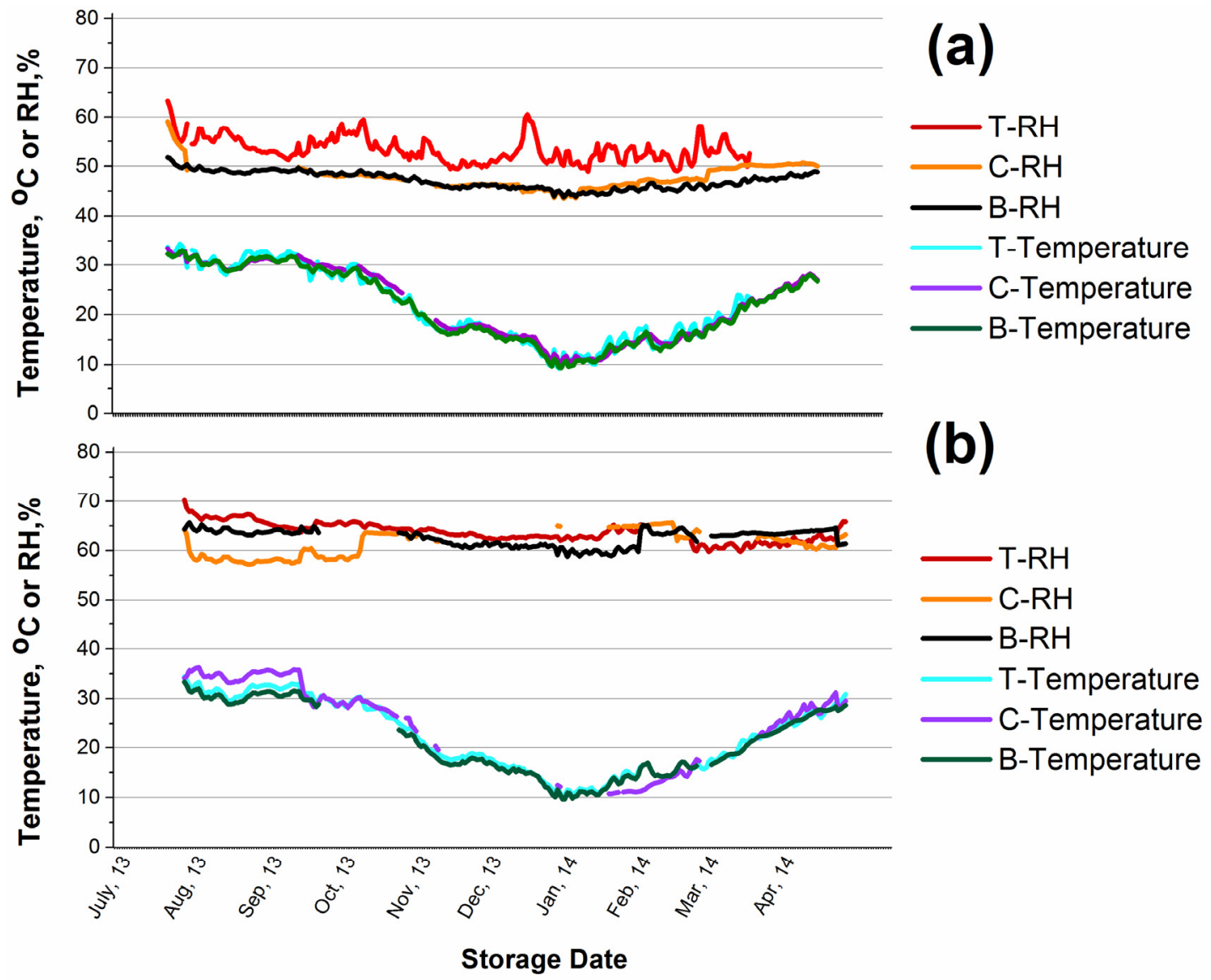

Figure 6. Temperature and relative humidity (RH) variations in hermetic bags H1 (a) and H4 (b) (treatment descriptions in table 1). Prefixes correspond to location of sensors in the storage structure: $T$, top; C, center; and B, bottom.

possible reason for decreased germination in cereals is degeneration of vital enzymes due to denaturation and coagulation of protein molecules during storage (Weidner et al., 1996). For rice and maize, germination of seed was $85 \%$ or more for periods up to 9 months, while conventional storage in jute bags reduced germination to $76 \%$ to $14 \%$ within 3 months (Villers et al., 2010). For dry wheat (12.5\% m.c.), germination percentages decreased from $93 \%$ to $87 \%$ while for moist wheat ( $16.4 \%$ m.c.), germination percentages decreased from $95 \%$ to $40 \%$ during the same period (Bartosik et al., 2008). In this study, germination rates for hermetic bags were similar and germination rates for gunny bags were higher than those reported in Villers et al. (2010). Germination percentage in gunny bags declined rapidly partly due to the early onset of natural infestation of insects whereas the other two structures resisted infestation. There was no significant variation in germination rates of wheat in hermetic bags with approximately $12 \%$ and $14 \%$ initial m.c. in the current study (table 2).

\section{Insect-Damaged Grain Percentage}

An important goal for any storage technique is its ability to prevent insect infestation from developing in the stored grain. Only Rhyzopertha dominica was identified upon visual inspection of affected structures and grain. After 9 months, no insect-damaged grain kernels were detected in the hermetic bags $\mathrm{H} 1$ and $\mathrm{H} 3$. For hermetic bags $\mathrm{H} 2$ and $\mathrm{H} 4$, which were deliberately infested by 80 adult specimens of Rhyzopertha dominica each, insect-damaged grain percentage stabilized at $0.33 \%$, indicative of containment of the infestation after initial damage. Mean insect-damaged grain percentage value was $0.2 \%$ for hermetic bags with low moistures ( $\mathrm{H} 1$ and $\mathrm{H} 2)$ as well as high moistures (H3 and $\mathrm{H} 4)$. De Groote et al. (2013) reported hermetic storage of maize prevented infestation of insect pests without application of insecticides. For metallic bins, insect-damaged grain percentage peaked at $2.2 \%$ while gunny bag piles were the worst affected with $8 \%$ of sampled grain found to be insectdamaged (table 2). The extent of grain damage was greatest in the gunny bags as the grain was easily accessible to the insects. Rhyzopertha dominica was the insect identified in both gunny bags and metallic bins.

\section{Milling Yield Percentage}

Milling yields of wheat from all structures increased gradually during the first 5 months $(7 \%$ to $10 \%)$ and then displayed a gradual decrease over time (table 2). Similar behavior has been reported in a number of previous studies (Shellenberger, 1939; Rao et al., 1978; Posner and Deyoe, 1986; Ariyama and Khan, 1990). Posner and Deyoe (1986) reported an increased flour extraction from $2 \%$ to $5 \%$ for the first five months; this is probably due to gradual increase in molecular weights of proteins in stored wheat as observed using gel chromatography by Rao et al. (1978). At the end of the nine month storage, the milling yield of wheat in all 

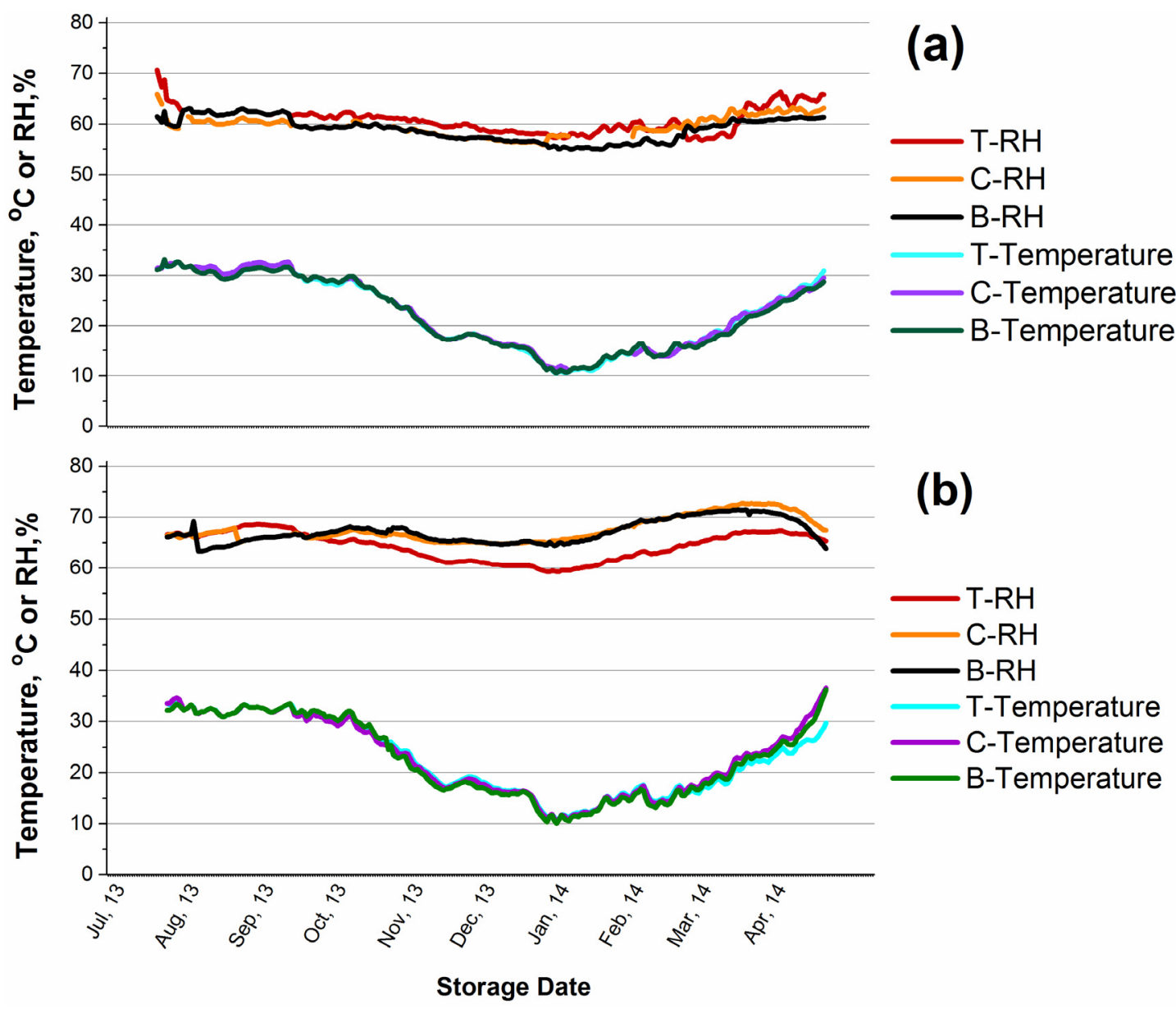

Figure 7. Temperature and relative humidy (RH) variations in metallic bin M1 (a) and gunny bag pile B2 (b) (treatment descriptions in table 1). Prefixes correspond to location of sensors in the storage structure: $T$, top; $C$, center; and $B$, bottom.

the storage structures was similar. However, it must be taken into account that only healthy wheat grains after removing insect-damaged kernels were processed for milling yields.

Future studies may incorporate $\mathrm{O}_{2}$ sensors and include other crops grown in the region like rice, mustard and pulses. Further experiments could document moisture migration in hermetic bags under north Indian weather conditions at conditions at Hisar, Haryana.

\section{Conclusions}

Four hermetic bags, two metallic bins, and two gunny bag piles each containing 1 tonne of wheat were instrumented with temperature, relative humidity, and carbon dioxide sensors under north Indian conditions at Hisar, Haryana. Representative samples from each storage structure were collected each month and tested for moisture, germination, insectdamaged grain and milling yield. Wheat stored in hermetic bags maintained $87 \%$ viability; for metallic bins and gunny bags these numbers were $82 \%$ and $73 \%$, respectively, after nine months of storage. Due to the limited range of initial wheat moisture content (11\%-13\%) and decreases in m.c. to safe levels during storage, it was not possible to quantify the effects of low $(<11 \%)$ and high $(>14 \%)$ initial moisture contents on wheat quality during hermetic storage. No insectdamaged grains were detected in two hermetic bags while (a)

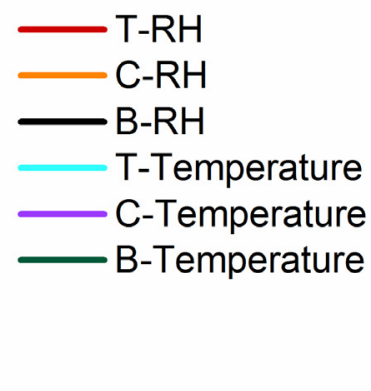

(b)

bags which were infested had $0.33 \%$ damaged grain during the last 4 months of storage, indicating containment. Mean insect-damaged grain percentage was $0.2 \%$ for both low and high initial m.c. hermetic bags. Insect-damaged grain percentages were $2.2 \%$ and $8 \%$, respectively, for metallic and gunny bag storage methods. Wheat m.c. in all the three storage structures were affected by surrounding ambient conditions. Hermetic bags experienced moisture migration as attested by $2-3$ percentage points' moisture variation in wheat samples. Milling yields, ascertained after removing insect-damaged kernels were lower for gunny bags compared to two other treatments. Hermetic bags maintained stored grain quality and protected wheat from insect infestation more than conventional structures. Hermetic bags can be an effective solution for reducing storage losses of wheat in India.

\section{ACKNOWLEDGEMENTS}

Authors acknowledge partial support provided by the ADM Institute for the Prevention of Postharvest Loss at the University of Illinois at Urbana-Champaign. The team is also thankful to Dr. K. S. Khokhar, Dr. S. S. Siwach, Dr. R. B. Grewal and Dr. R. P. Narwal from CCS Haryana Agricultural University, Hisar, India for their support and guidance during this project. 
Table 2. Quality characteristics of wheat in different structures during 9 month storage. ${ }^{\text {a] }}$

\begin{tabular}{|c|c|c|c|c|c|}
\hline & Initial & 3-month & 6-month & 9-month & $\begin{array}{c}\text { Mean } \\
\text { (across storage time) }\end{array}$ \\
\hline \multicolumn{6}{|l|}{ Moisture (\%) } \\
\hline Hermetic bags (low m.c.) & $11.8 \pm 0.1$ & $9.4 \pm 0.4$ & $10.1 \pm 0.1$ & $8.3 \pm 0.3$ & $9.9 \pm 1.3 \mathrm{~d}^{[\mathrm{b}]}$ \\
\hline Hermetic bags (high m.c.) & $13.4 \pm 0.0$ & $12.0 \pm 0.1$ & $11.8 \pm 0.1$ & $11.3 \pm 0.1$ & $12.1 \pm 0.9 \mathrm{a}$ \\
\hline Metallic bins & $11.8 \pm 0.1$ & $10.6 \pm 0.8$ & $11.3 \pm 0.2$ & $8.6 \pm 0.0$ & $10.5 \pm 1.3 c$ \\
\hline Gunny bags & $12.2 \pm 0.1$ & $12.0 \pm 0.3$ & $13.9 \pm 0.0$ & $8.3 \pm 0.0$ & $11.6 \pm 2.2 b$ \\
\hline Mean (across structures) & $12.3 \pm 0.7 \mathrm{~A}^{[\mathrm{c}]}$ & $11.0 \pm 1.2 \mathrm{C}$ & $11.8 \pm 1.5 \mathrm{~B}$ & $9.1 \pm 1.3 \mathrm{D}$ & \\
\hline \multicolumn{6}{|l|}{ Germination (\%) } \\
\hline Hermetic bags (low m.c.) & $96.0 \pm 0.0$ & $92.0 \pm 1.4$ & $89.5 \pm 0.7$ & $89.5 \pm 0.7$ & $91.3 \pm 3.5 \mathrm{a}$ \\
\hline Hermetic bags (high m.c.) & $95.5 \pm 0.7$ & $92.0 \pm 0.0$ & $88.5 \pm 0.7$ & $86.5 \pm 0.7$ & $90.6 \pm 3.7 a$ \\
\hline Metallic bins & $96.0 \pm 0.0$ & $90.5 \pm 0.7$ & $88.0 \pm 1.4$ & $81.0 \pm 1.4$ & $88.9 \pm 5.8 b$ \\
\hline Gunny bags & $96.0 \pm 0.0$ & $85.0 \pm 1.4$ & $83.5 \pm 0.7$ & $73.5 \pm 2.1$ & $84.5 \pm 8.6 c$ \\
\hline Mean (across structures) & $95.9 \pm 0.4 \mathrm{~A}$ & $89.9 \pm 3.2 \mathrm{~B}$ & $97.4 \pm 2.6 \mathrm{C}$ & $82.1 \pm 6.0 \mathrm{D}$ & \\
\hline \multicolumn{6}{|l|}{ Insect-damaged grain (\%) } \\
\hline Hermetic bags (low m.c.) & $0.0 \pm 0.0$ & $0.0 \pm 0.0$ & $0.2 \pm 0.2$ & $0.2 \pm 0.2$ & $0.1 \pm 0.1 \mathrm{c}$ \\
\hline Hermetic bags (high m.c.) & $0.0 \pm 0.0$ & $0.5 \pm 0.7$ & $0.2 \pm 0.2$ & $0.2 \pm 0.2$ & $0.2 \pm 0.4 \mathrm{c}$ \\
\hline Metallic bins & $0.0 \pm 0.0$ & $1.2 \pm 0.2$ & $1.5 \pm 0.2$ & $2.2 \pm 0.2$ & $1.2 \pm 0.8 b$ \\
\hline Gunny bags & $0.0 \pm 0.0$ & $5.0 \pm 0.0$ & $6.1 \pm 0.7$ & $8.0 \pm 0.5$ & $4.8 \pm 3.2 \mathrm{a}$ \\
\hline Mean (across structures) & $0.0 \pm 0.0 \mathrm{C}$ & $1.7 \pm 2.1 \mathrm{~B}$ & $2.0 \pm 2.6 \mathrm{~B}$ & $2.7 \pm 3.4 \mathrm{~A}$ & \\
\hline \multicolumn{6}{|l|}{ Milling yield (\%) } \\
\hline Hermetic bags (low m.c.) & $64.9 \pm 0.6$ & $74.4 \pm 3.9$ & $73.6 \pm 1.6$ & $70.1 \pm 0.3$ & $70.8 \pm 4.3 \mathrm{ab}$ \\
\hline Hermetic bags (high m.c.) & $65.2 \pm 0.6$ & $73.7 \pm 0.3$ & $75.1 \pm 2.7$ & $69.0 \pm 0.6$ & $70.8 \pm 4.3 \mathrm{ab}$ \\
\hline Metallic bins & $66.0 \pm 0.6$ & $74.4 \pm 0.1$ & $76.9 \pm 1.2$ & $69.2 \pm 0.6$ & $71.6 \pm 4.6 \mathrm{a}$ \\
\hline Gunny bags & $66.1 \pm 0.3$ & $72.3 \pm 1.1$ & $70.5 \pm 1.1$ & $67.5 \pm 0.6$ & $69.1 \pm 2.7 b$ \\
\hline Mean (across structures) & $65.6 \pm 0.7 \mathrm{C}$ & $73.8 \pm 1.8 \mathrm{~A}$ & $74.1 \pm 2.8 \mathrm{~A}$ & $69.0 \pm 1.1 \mathrm{~B}$ & \\
\hline
\end{tabular}

[a] Values in the table are mean \pm SD from two replicates.

[b] Values followed by the same letter in the same column are not significantly different $(\mathrm{P}<0.05)$.

[c] Values followed by the same letter in the same row are not significantly different $(\mathrm{P}<0.05)$.

\section{REFERENCES}

AACC. (2002). Approved methods of American Association of Cereal Chemists. St. Paul, MN: American Association of Cereal Chemists.

Abalone, R., Gaston, A., Bartosik, R., Cardoso, L., \& Rodriguez, J. (2011). Gas concentration in the interstitial atmosphere of a wheat silo-bag. Part I: Model development and validation. $J$. Stored Prod. Res., 47(4), 268-275. http://dx.doi.org/10.1016/j.jspr.2011.05.004

AOAC. (2012). Official methods of analysis (19th ed.). Washington, DC: Association of Official Analytical Chemists.

Ariyama, T., \& Khan, K. (1990). Effect of laboratory sprouting and storage on physicochemical and breadmaking properties of hard red spring wheat. Ceral Chem., 67(1), 53-58.

ASSOCHAM. (2013). ASSOCHAM Press Releases. Postharvest losses may cross Rs. 2.50 lac crore by 2013-14. India: ASSOCHAM. Retrieved from http://www.assocham.org/prels/shownews-archive.php?id=4132

Banks, H. J., \& Annis, P. C. (1990). Comparative advantages of high $\mathrm{CO}_{2}$ and low $\mathrm{O}_{2}$ types of controlled atmospheres for grain storage. In L. Calderon, \& R. Barkai-Golan (Eds.), Food preservation by modified atmospheres (1st ed., pp. 93-122). Boca Raton, FL: CRC Press.

Barreto, A. A., Abalone, R., Gaston, A., \& Bartosik, R. (2013). Analysis of storage conditions of a wheat silo-bag for different weather conditions by computer simulation. Biosyst. Eng., 116(4), 497-508. http://dx.doi.org/10.1016/j.biosystemseng.2013.10.012

Bartosik, R., Rodriguez, J., \& Cardoso, L. (2008). Storage of corn, wheat, soybean and sunflower in hermetic plastic bags. Proc. Int. Grain Quality \& Technology Congress. Chicago, IL, USA.
Basavaraja, H., Mahajanashetti, S. B., \& Udagatti, N. C. (2007). Economic analysis of post-harvest losses in food grains in India: A case study of Karnataka. Agric. Economics Res. Rev., 20(1), 117-126.

Butts, C. L., Dorner, J. W., Lamb, M. C., Sorensen, R. B., \& Sanders, T. H. (2008). Storing peanuts in flexible hermetically sealed containers. ASABE Paper No. 084198. St. Joseph, MI: ASABE. http://dx.doi.org/10.13031/2013.24766

CIMMYT. (2009). Annual Report. Effective grain storage for better livelihoods of African Farmers Project. International Maize and Wheat Improvement Center. Nairobi, Kenya: CIMMYT.

Collins, P. J., Daglish, G. J., Pavic, H., \& Kopittke, R. A. (2005). Response of mixed-age cultures of phosphine-resistant and susceptible strains of lesser grain borer, Rhyzopertha dominica, to phosphine at a range of concentrations and exposure periods. J. Stored Prod. Res., 41(4), 373-385. http://dx.doi.org/10.1016/j.jspr.2004.05.002

Darby, J. A., \& Caddick, L. P. (2007). Review of grain harvest bag technology under Australian conditions. Clayton, Australia: CSIRO Entomology. Retrieved from https://publications.csiro.au/rpr/download?pid=procite:d0d5777 1-ffbb-4ffd-8fd4-de675a9a0448\&dsid=DS1

De Groote, H., Kimenju, S. C., Likhayo, P., Kanampiu, F., Tefera, T., \& Hellin, J. (2013). Effectiveness of hermetic systems in controlling maize storage pests in Kenya. J. Stored Prod. Res., 53, 27-36. http://dx.doi.org/10.1016/j.jspr.2013.01.001

Directorate of Wheat Research. (2013). Wheat scenario: A snippet. Karnal, India: ICAR. Retrieved from http://www.dwr.res.in/sites/default/files/Publications/wheatsnipp etissue\%202-2014.pdf

Food and Agriculture Organization. (1994). Agricultural engineering in development: Post-harvest operations and management of foodgrains. Rome, Italy: FAO. Retrieved from http://www.fao.org/docrep/t0522e/T0522E04.htm\#Post-harvest losses 
Food and Agriculture Organization. (2009). Rapid growth of selected Asian economies. Rome, Italy: FAO. Retrieved from http://www.fao.org/docrep/009/ag087e/AG087E04.htm

Garcia-Lara, S., Ortiz-Islas, S., \& Villers, P. (2013). Portable hermetic storage bag resistant to Prostephanus truncatus, Rhyzopertha dominica, and Callosobruchus maculatus. J. Stored Prod. Res., 54, 23-25. http://dx.doi.org/10.1016/j.jspr.2013.04.001

Gaston, A., Abalone, R., Bartosik, R. E., \& Rodriguez, J. C. (2009). Mathematical modelling of heat and moisture transfer of wheat stored in plastic bags (silobags). Biosyst. Eng., 104(1), 72-85. http://dx.doi.org/10.1016/j.biosystemseng.2009.06.012

Grover, D. K., \& Singh, J. M. (2013). Post-harvest losses in wheat crop in Punjab: Past and present. Agril. Econ. Res. Rev., 26(2), 293-297.

Gustavsson, J., Cederberg, C., Sonesson, U., Otterdijk, R. V., \& Meybeck, A. (2010). Global food losses and food wastage: Extent, causes and prevention. Rome, Italy: FAO. Retrieved from http://www.fao.org/ag/ags/agsdivision/publications/publication/en/c/74045/

Indian Council of Agricultural Research. (2014). Foodgrains production in 2013-14 likely to cross 264 MT. Delhi, India: ICAR. Retrieved from http://www.icar.org.in/en/node/7665

ISTA. (2011). International rules for seed testing, Chapter 5: The germination test. Baserdorf, Switzerland: International Seed Testing Association.

Jayas, D. S., \& Jeyamkondan, S. (2002). Modified atmosphere storage of grains, meats, fruits and vegetables. Biosyst. Eng., 82(3), 235-251. http://dx.doi.org/10.1006/bioe.2002.0080

Kader, A. A. (2005). Increasing food availability by reducing postharvest losses of fresh produce. Acta Hort., 682, 2169-2176. http://dx.doi.org/10.17660/ActaHortic.2005.682.296

Kumawat, K. C. (2007). Assessment of losses due to insect pests under wheat storage practices in semi arid region. Annals of Plant Protection Sciences, 15(1), 97-100.

Lorini, I., Collins, P. J., Daglish, G. J., Nayak, M. K., \& Pavic, H. (2007). Detection and characterisation of strong resistance to phosphine in Brazilian Rhyzopertha dominica (F.) (Coleoptera: Bostrychidae). Pest Manag. Sci., 63(4), 358-364. http://dx.doi.org/10.1002/ps.1344

National Sample Survey Organization. (2010). Nutritional intake in India. Delhi, India: NSSO. Retrieved from $\mathrm{http}: / / \mathrm{www}$. indiaenvironmentportal.org.in/files/file/nutrition $\% 20$ intake $\% 20 \mathrm{in} \% 20$ india.pdf

Navarro, S. (2006). Modified atmospheres for the control of storedproduct insects and mites. In J. W. Heaps (Ed.), Insect management for food storage and processing (2nd. ed., pp. 105146). St. Paul, MN: AACC Int.

Navarro, S. (2012). Global challenges for the successful application of MA and hermetic storage. Proc. 9th Int. Conf. on Controlled Atmosphere and Fumigation in Stored Products, (pp. 429-439). Antalia, Turkey.

Navarro, S., \& Donahaye, J. (2005). Innovative environmentally friendly technologies to maintain quality of durable agricultural produce. In S. Ben-Yehoshua (Ed.), Environmentally friendly technologies for agricultural produce quality (1st ed., pp. 203260). Boca Raton, FL: CRC Press. http://dx.doi.org/10.1201/9780203500361.ch8

Nayak, M. K., Collins, P. J., Pavic, H., \& Kopittke, R. A. (2003). Inhibition of egg development by phosphine in the cosmopolitan pest of stored products Liposcelis bostrychophila (Psocoptera: Liposcelididae). Pest Manag. Sci., 59(11), 1191-1196. http://dx.doi.org/10.1002/ps.753
Ochandio, D. C., Cardoso, L. M., Bartosik, R. E., Torre, D. A., Rodriguez, J. C., \& Massigoge, J. (2010). Storage quality malting barley in hermetic plastic bags. Proc. 10th Int. Conf. on Stored Product Protection, (pp. 331-337).

Ochandio, D., Cardoso, L., Bartosik, R., de la Torre, D., Rodríguez, J., \& Massigoge, .J (2010). Storage of canola in hermetic plastic bags. Proceedings of the International Working Conference on Stored Product Protection, June 27-July 2, Estoril, Portugal.

Person Jr, N. K., \& Sorenson Jr, J. W. (1970). Use of gaseous nitrogen for controlling stored-product insects in cereal grains. Cereal Chem., 47(6), 679-686.

Posner, E. S., \& Deyoe, C. W. (1986). Changes in milling properties of newly harvested hard wheat during storage. Cereal Chem., 63(5), 451-456.

Rao, V. S., Vakil, U. K., \& Sreenivasan, A. (1978). Comparative studies on physicochemical and baking properties of newly harvested and stored Indian varieties of wheat. J. Sci. Food Agric., 29(2), 155-164. http://dx.doi.org/10.1002/jsfa.2740290213

SDC. (2008a). Fighting poverty with metal silo and job creation. Berne, Switzerland: Latin America Section: Swiss Agency for Development and Cooperation.

SDC. (2008b). Metal silos. Manual for manufacturing metal silos for grain storage. 58-118. Berne, Switzerland: Swiss Agency for Development and Cooperation.

Shellenberger, J. (1939). Newly harvested wheats showed an improvement in milling extraction and baking characteristics during several months of storage. Cereal Chem., 25, 676.

Subramanyam, B., Channiaish, L. H., Campabadal, C., Lawrence, J., Cardoso, L., \& Maier, D. E. (2012). Evaluation of silo bags for temporary storage of wheat. Proc. 9th Int. Conf. on Controlled Atmosphere and Fumigation in Stored Products, (pp. 429-439). Antalia, Turkey.

Tefera, T., Kanampiu, F., Groote, H. D., Hellin, J., Mugo, S., Kimenju, S., Beyene, Y., Boddupalli, P. M., Shiferaw, B. \& Banziger, M. (2011). The metal silo: an effective grain storage technology for reducing post-harvest insect and pathogen losses in maize while improving smallholder farmers' food security in developing countries. Crop Prot., 30(3),240-245.

Villers, P., Bruin, T. d., \& Navarro, S. (2006). Development and applications of the hermetic storage technology. Proc. 9th Int. Conf. on Stored Product Protection, (pp. 719-729). Sao Paulo, Brazil.

Villers, P., Navarro, S., \& Bruin, T. d. (2010). New applications of hermetic storage for grain storage and transport. Proc. 10th Int. Conf. on Stored Products Protection, (pp. 446-452). Estoril, Portugal.

Weidner, S., Paprocka, J., \& Lukaszewicz, D. (1996). Changes in free, esterified and glycosidic phenolic acids in cereal grains during the after-ripening. Seed Sci. Technol., 24(1), 107-114.

Yadav, J. L., \& Garg, M. K. (2010). Status of storage practices in Mohindergarh district of Haryana (India). Environ. Ecol., 28(2B), 1238-1242.

Yusuf, B. L., \& He, Y. (2011). Design, development and techniques for controlling grains post-harvest losses with metal silo for small and medium scale farmers. African J. Biotechnol., 10(65), 14552-14561. https://doi.org/10.5897/AJB11.1845 